\title{
PEMODELAN KOPERASI WANITA DALAM PENINGKATAN KESEJAHTERAAN PEREMPUAN DI KABUPATEN BLITAR
}

\author{
Oleh: \\ Nurul Farida \\ Suprianto \\ Universitas Islam Balitar Blitar \\ Email: nurifarida27@gmail.com.
}

\begin{abstract}
ABSTRAK.
Kesejahteraan hidup adalah merupakan harapan setiap masyarakat dan kesejahteraan masyarakat merupakan tujuan dari pemerintah. Untuk mewujudkan masyarakat yang adil, makmur dan sejahtera diperlukan berbagai macam program kegiatan masyarakat. Penelitian ini bertujuan untuk memberikan kontribsi pemodelan koperasi wanita dalam peningkatan kesejahteraan. Koperasi Wanita adalah salah satu kelompok masyarakat yang tujuanya untuk meningkatkan kaum perempuan mampu meningkatkan kesejahteraan hidupny melalui kegiatan-kegiatan yang dilakukan. Dari hasil penelitian di lapang didapat bahwa yang mempengaruhi tingkat kesejahteraan adalah bahagia yaitu mereka akan merasakan kebahagiaan pada saat tercukupi kebutuhan hidupnya, pendidikan yaitu dimana mampu menjagkau biaya pendidikan dan kualitas hidup yaitu adanya pengakuan dan kepercayaan masyarakat akan kemampuanya sehingga mereka lebih bisa mengkautalisasikan diri.
\end{abstract}

\section{ABSTRACT}

Life welfare is the hope of every society and society welfare is the goal of the goverment to create a fair society, properous and safe is required some kind progam of the activities community. This research is to contribute the modeling of women cooperation in improving of welfare. Women cooperation is one of groups community that have purpose to increase women ability to increase his life by activities what he did. From the result of the reseach can be conclusion that the affect the level of welfare is happiness, they will feel happy when fulfilled necessities of her life, education wich is can reach the cost of education and quality of life, wich is recognition and public trust about her ability so they can be more quality theirself.

\section{PENDAHULUAN}

Salah satu tujuan pembangunan adalah upaya mewujudkan masyarakat yang sejahtera kesejahteraan erat kaitannya dengan tujuan Negara Indonesia. Negara didirikan, dipertahankan dan dikembangkan untuk kepentingan seluruh rakyat yaitu untuk menjamin dan memajukan kesejahteraan umum. Hal ini secara nyata dituangkan dalam pembukaan UUD 1945 yang berbunyi:"kemudian daripada itu untuk membentuk suatu pemerintah Negara Indonesa yang melindungi segenap bangsa Indonesia dan seluruh tumpah darah Indonesia dan untuk memajukan kesejahteraan umum, mencerdaskan kehidupan bangsa dan ikut melaksanakan ketertiban dunia 
berdasarkan kemerdekaan, perdamaian, abadi dan keadilan sosial, maka disusunlah kemerdekaan kebangsaan Indonesia itu dalam suatu UndangUndang dasar Negara Indonesia”.

Dengan melihat pembukaan UUD 1945 diatas dapat dikemukakan bahwa tujuan Negara Indonesia adalah melindungi seluruh bangsa dan tumpah darah Indonesia, memajukan kesejahteraan umum dan mencerdaskan kehidupan bangsa dan ikut serta melaksanakan ketertiban dunia berdasarkan kemerdekaan, perdamaian abadi dan keadilan sosial. Oleh karenanya Negara berkewajiban untuk memenuhi kebutuhan hidup warga negaranya. Sebagaimana dinyatakan oleh Aristoteles bahwa Negara dibentuk untuk menyelenggarakan hidup yang baik bagi semua warganya.

Namun demikian, kesejahteraan umum (keadilan sosial) sebagai tujuan Negara bukan berarti kewajiban Negara untuk menciptakan kesejahteraan seluruh rakyat, sehingga rakyat tidak berupaya untuk mewujudkan kesejahteraan bagi dirinya sendiri, akan tetapi rakyat mempunyai hak dan kewajiban untuk mencapai kesejahteraannya. Negara hanya bertugas untuk menciptakan suasana atau keadaan yang memungkinkan rakyat dapat menikmati hak-haknya sebagai warga Negara dan mencapai kesejahteraan mereka semaksimal mungkin. Dalam rangka mewujudkan kesejahteraan tersebut komponen utama yang harus dipenuhi adalah adanya kepastian hukum dan tersedianya barang dan jasa kebutuhan hidup bagi semua warga Negara.

Perwujudan masyarakat yang adil dan makmur secara lebih rinci disebutkan oleh Kirdi Dipoyudo berupa tersedianya:

1. cukup sandang dan pangan dan perumahan yang layak, sehingga ia dapat hidup dengan aman tidak perlu merasa cemas dalam menghadapi kehidupan di masa yang akan datang;

2. fasilitas kesehatan termasuk tenaga medis, obat-obatan, rumah sakit dan pusat kesehatan masyarakat dengan perlengkapan dan tenaga yang memadai dengan biaya yang terjangkau daya beli masyarakat;

3. kesempatasn pendidikan dalam segala tingkat baik pendidikan umum atau professional kejuruan;

4. jaminan hari tua, sehingga orang tidak takut mengahadapi masa tuanya pada saat dia tidak bisa berdaya mencari nafkah;

5. sarana perhubungan secukupnya, sehingga dia dengan mudah, cepat dan murah untuk bergerak dalam mengahadapi segala urusannya;

6. sarana komunikasi seperlunya, sehingga dapat mengadakan hubungan dengan orang lain melalui pos, telepon, telegram dan radio dengan cepat dan mudah;

7. kesempatan kereja yang sesuai keinginan dan kecakapannya;

8. Kesempatan untuk mengembangkan dan menikmati kebudayaan, menyempurnakan hidup moral keagamaan dan kehidupan intelektualnya;

9. Memungkinkan untuk istirahat dan menikmati hiburan;

Terwujudnya kesejahteraan warga Negara dapat menciptakan struktur masyarakat atau Negara yang seimbang dan teratur dengan memberi 
kesempatan kepada semua warga Negara untuk membangun suatu kehidupan yang layak dan mereka yang lemah mendapatkan bantuan dari pemerintah. Karena pemerintah sebagai pimpinan Negara mempunyai tugas utama untuk memajukan kesejahteraan umum. Tidak hanya kesejahteraan lahir tetapi juga kesejahteraan

bathin.

Oleh karena begitu luas jangkauan kesejahteraan yang meliputi lahir dan bathin ini, kesejahteraan umum berarti diakui dan dihormatinya hak hak dasar warga Negara dan tersedianya barang dan jasa keperluan hidup yang terjangkau oleh daya beli rakyat. Dalam rangka mewujudkan hal ini Negara harus melakukan beberapa hal;

1. Wajib menetapkan dan menegakkan hak-hak asasi;

2. Wajib mengusahakan agar barang dan jasa keperluan hidup dihasilkan dan atau didatangkan mencukupi keperluan hidup warga Negara dan dapat didistribusikan dengan cepat, aman dan dijual dengan harga yang wajar seimbang dengan daya beli warga Negara;

3. Harus mengusahakan setiap warga Negara mampu bekerja secara produktif dengan syarat-syarat kerja yang wajar dan gaji yang mencukupi kebutuhan hidup dan keluarganya;

4. Wajib memberikan bantuan seperlunya kepada mereka yang terganggu secara fisik dan mentalnya.

Biro Pusat Statistik Indonesia (2000) menerangkan bahwa, guna melihat tingkat kesejahteraan rumah tangga suatu wilayah ada beberapa indikator yang dapat dijadikan ukuran, antara lain:

1. Tingkat pendapatan keluarga

2. Komposisi pengeluaran rumah tangga dengan membandingkan pengeluaran untuk pangan dengan non pangan

3. Tingkat pendidikan keluarga

4. Tingkat kesehatan keluarga, dan

5. Kondisi perumahan serta fasilitas yang dimiliki dalam rumah tangga.

\section{Makna Penting Kesejahteraan Masyarakat}

Istilah kesejahteraan berasal dari kata sejahtera yang berarti aman sentosa dan makmur dan dapat berarti selamat terlepas dari gangguan. Sedangkan kesejahteraan diartikan dengan hal atau keadaan sejahtera, keamanan, keselamatan dan ketentraman . Istilah kesejahteraan erat kaitannya dengan tujuan Negara Indonesia. Negara didirikan, dipertahankan dan dikembangkan untuk kepentingan seluruh rakyat yaitu untuk manjamin dan memajukan kesejahteraan umum. Hal ini secara nyata dituangkan dalam pembukaan UUD 1945. Namun demikian, kesejahteraan umum sebagai tujuan Negara bukan berarti kewajiban Negara untuk menciptakan kesejahteraan seluruh rakyat, sehingga rakyat tidak berupaya untuk mewujudkan kesejahteraan bagi dirinya sendiri, akan tetapi rakyat mempunyai hak dan kewajiban untuk mencapai kesejahteraannya. Negara hanya bertugas untuk menciptakan suasana atau keadaan yang memungkinkan rakyat dapat menikmati hak-haknya sebagai warga Negara dan mencapai kesejahteraan mereka semaksimal mungkin. Dalam rangka mewujudkan kesejahteraan tersebut komponen utama yang 
harus dipenuhi adalah adanya kepastian hukum dan tersedianya barang dan jasa kebutuhan hidup bagi semua warga Negara

Kesejahteraan sebagai suatu kondisi (keadaan) dapat terlihat dari Rumusan Undang-Undang Republik Indonesia Nomor 6 Tahun 1974 tentang ketentuan-ketentuan pokok kesejahteraan sosial pasal 2 ayat 1 " Kesejahteraan sosial ialah suatu tata kehidupan dan penghidupan sosial materil maupun spirituil yang diliputi oleh rasa keselamatan, kesusilaaan, dan ketentraman lahir dan batin, yang memungkinkan bagi setiap warga negara untuk mengadakan usaha pemenuhan kebutuhan-kebutuhan jasmaniah, rohaniah dan sosial yang sebaik-baiknya bagi diri sendiri, keluarga serta masyarakat dengan menjunjung tinggi hak-hak asasi serta kewajiban manusia sesuai dengan Pancasila"

Sedangkan pengertian kesejahteraan Masyarakat Menurut Walter Friedlander dalam Isbandi Ruminto (1994:4)"Kesejahteraan Masyarakat ialah "sistem yang teroganisir dari institusi dan pelayanan sosial, yang dirancang untuk membantu individu ataupun kelompok agar dapat mencapai standar hidup dan kesehatan yang lebih baik".

Berdasarkan pernyataan diatas, kesejahteraan sosial tidak akan ada maknanya jika tidak diterapkan dalam bentuk usaha kesejahteraan sosial yang nyata dimana menyangkut kesejahteraan masyarakat. Konsep kesejahteraan sosial menurut Nasikun (1993) dapat dirumuskan sebagai makna dari konsep martabat manusia yang dapat dilihat dari empat indikator yaitu:

1. Rasa aman (security),

2. Kesejahteraan (welfare),

3. Kebebasan (freedom),

4. Jati diri (identity)

Menurut Kolle (1974) dalam Bintaro (1989: 44), kesejahteraan dapat diukur dari beberapa aspek kehidupan:

1. Dengan melihat kualitas hidup dari segi materi, seperti kualitas rumah, bahan pangan dan sebagainya;

2. Dengan melihat kualitas hidup dari segi fisik, seperti kesehatan tubuh, lingkungan alam dan sebagainya;

3. Dengan melihat kualitas hidup dari segi mental, seperti fasilitas pendidikan, lingkungan budaya dan sebagainya;

4. Dengan melihat kualitas hidup dari segi spiritual seperti moral, etika, keserasian penyesuaian, dan sebagainya.

Sedangkan menurut Drewnoski (1974) dalam Bintarto (1989: 45), melihat konsep kesejahteraan dari tiga aspek;

1. Dengan melihat pada tingkat perkembangan fisik (somatic status), seperti nutrisi, kesehatan, harapan hidup dan sebagainya,

2. Dengan melihat pada tingkat mentalnya, (mental/ educational status) seperti pendidikan, pekerjaan, dan sebagainya,

3. Dengan melihat pada intregrasi dan kedudukan sosial (social status).

Dalam memahami realitas tingkat kesejahteraan, pada dasarnya terdapat beberapa faktor yang menyebabkan terjadinya kesenjangan tingkat kesejahteraan anatara lain: 
1. Sosial ekonomi rumah tangga atau masyarakat,

2. Struktur kegiatan ekonomi sektoral yang menjadi dasar kegiatan produksi rumah tangga atau masyarakat,

3. Potensi regional (sumberdaya alam, lingkungan dan insfrastruktur) yang mempengaruhi perkembangan struktur kegiatan produksi, dan Kondisi kelembagaan yang membentuk jaringan kerja produksi dan pemasaran pada skala lokal, regional dan global (Taslim, 2004: 33

\section{Ciri-ciri masyarakat sejahtera:}

1. Masyarakat yang mampu memenuhi kebutuhan hidupnya;

2. Memiliki tempat tinggal yang layak;

3. Dapat bersekolah;

4. Masyarakatnya mandiri

\section{Makna Kesejahteraan Masyarakat}

Sen (2000), menyebutkan bahwa welfare economic adalah wujud dari proses rasional ke arah melepaskan masyarakat dari hambatan yang dimilikinya untuk memperoleh sebuah kemajuan dalam hal pemenuhan tersebut meliputi : kebutuhan pokok, kualitas hidup dan pola pikir yang lebih maju.

Lain halnya dengan Nicholson (1992), ia menyatakan mengenai prinsip dari kesejahteraan sosial yaitu dimana kesejahteraan sosial yang maksimum akan tercapai jika tidak ada seorangpun yang merasa dirugikan dalam proses tersebut. Sedangkan Etzioni A (1999) mengatakan bahwa dalam pembangunan ekonomi, kedudukan individu sebagai makluk sosial harus diupayakan agar tercapai tujuan dari pemberdayaan yaitu kesejahteraan.

\section{Perumusan Masalah}

Berdasarkan latar belakang diatas, maka rumusan masalah utama dalam penelitian ini adalah "Pemodelan Koperasi Wanita Dalam Peningkatan Kesejahteraan di Kabupaten Blitar?”.

Dalam rumusan masalah ini akhirnya di dapat pertanyaan masalah adalah:

1. Bagiamanakah Implementasi Kesejahteraan di Koperasi Wanita Kabupetan Blitar?

2. Bagaimanakah Pemodelan dalam Peningkatan kesejahteraan di Koperasi Wanita Kabupten Blitar?

\section{Tujuan Penelitian}

Berdasarkan Rumusan Rumusan Masalah, maka penelitian ini mempunyai tujuan yaitu :

1. Untuk Mengkaji Implementasi Kesejahteraan aggota Koperasi Wanita di Kabupaten Blitar.

2. Untuk Mengkaji dan merumuskan pemodelan kesejahteraan anggota Koperasi Wanita di Kabupaten Blitar. 


\section{Manfaat Penelitian}

Penelitian ini akan memberikan kontribusi dalam merumuskan pemodelan Kesejahteraan Anggota dan Pengurus Koperasi Wanita di lingkungan pemangku kebijakan pemerintah, sehingga program Koperasi Wanita yang dilaksanakan di Jawa Timur dapat secara efektif dalam pelaksanaanya.

Penelitian ini juga diharapkan akan dapat mengembangkan teori Manajemen Sumber Daya Manusia (MSDM) dan Manajemen Kesejahteraan yang akan menjadi pembelajaran dan sebagai acuan bagi pemangku kepentingan .

\section{METODE PENELITIAN \\ Jenis Penelitian}

Penelitian ini mengacu pada jenis pendekatan dimana yang dipilih dalam penelitian ini, yaitu Penelitian Diskriptif Kualitatif. Penelitian ini bertujuan untuk membuat deskriptif secara sistematif, faktual dan akurat tentang faktafakta atau sifat-sifat objek tertentu.

Dalam penelitian ini memaparkan sistuasi tidak menguji hipotesa atau membuat prediksi dengan langkah-langkah sebagai berikut :

1. Mendiskripsikan masalah-masalah secara tegas

2. Menentukan bagaimana prosedur penelitian

3. Mengumpulkan data

4. Pengolahan dan menganalisanya

\section{Subyek dan Obyek Penelitian}

Subjek penelitian ini adalah semua masyarakat atau semua perempuan yang tergabung menjadi anggota Koperasi wanita di Kabupaten Blitar.

Pengambilan sumber data dalam penelitian ini menggunakan "purpose sampling" yaitu pengambilan sampel didasarkan pada pilihan peniliti tentang aspek apa dan siap yang dijadikan fokus pada saat situasi tertentu dan saat ini terus menerus sepanjang penelitia, sampling bersifat purposive yaitu tergantung pada tujuan fokus suatu saat dengan sesuai kriteria sampel yang ditentukan oleh peneliti. Adapun kriteria sampel :

1. Masyarakat yang tergabung menjadi anggota koperasi Wanita.

2. Pengelola Koperasi Wanita (pengurus Koperasi Wanita)

3. Pemerintah

\section{Jenis dan Sumber Data}

Data Primer

Penelitian lapangan ini dilakukan untuk mendapatkan data-data yang berhubungan dengan objek penelitian secara langsung di lapangan

\section{Data Skunder}

Yaitu dengan cara mempelajari, meneliti, mengkaji serta menelaah literatur-literatur yang ada kaitanya dengan masalah yang diteliti.

\section{Metode Pengumpulan data}

\section{Observasi Berperan Aktif}


Observasi, cara pengumpulan data yang dilakukan dengan cara melakukan pengamatan langsung pada obyek penelitian serta melakukan pencatatan secara sistematis mengenai hal-hal yang diteliti.

\section{Wawancara}

Interview (wawancara), proses pengumpulan data yang dilakukan dengan cara tanya jawab sambil bertatap muka secara langsung dengan dinas koperasi dan UMKM Kabupaten Blitar, kelompok-kelompok Koperasi Wanita, tokoh masyarakat.

\section{Dokumentasi}

Dokumen merupakan catatan peristiwa yang sudah berlaku, misalnya catatan buku harian koperasi wanita, sejarah perkembangan, cerita, biografi, peraturan dan kebijakan-kebijakan dalam koperasi wanital

\section{Triangulasi}

Yaitu penggabungan dari ketiga teknik diatas yaitu, observasi, wawancara dan dokumentasi. Dalam teknik pengumpulan data triangulasi ini peneliti bisa langsung mengumpulkan data dan sekaligs menguji kredibilitas data, yaitu mengecek kredibilitas data dengan berbagai teknik pengumpulan data dari berbagai sumber.

\section{Kerangka Konsep Penelitian.}

Gambar 1.

Kerangka Konsep Penelitian.

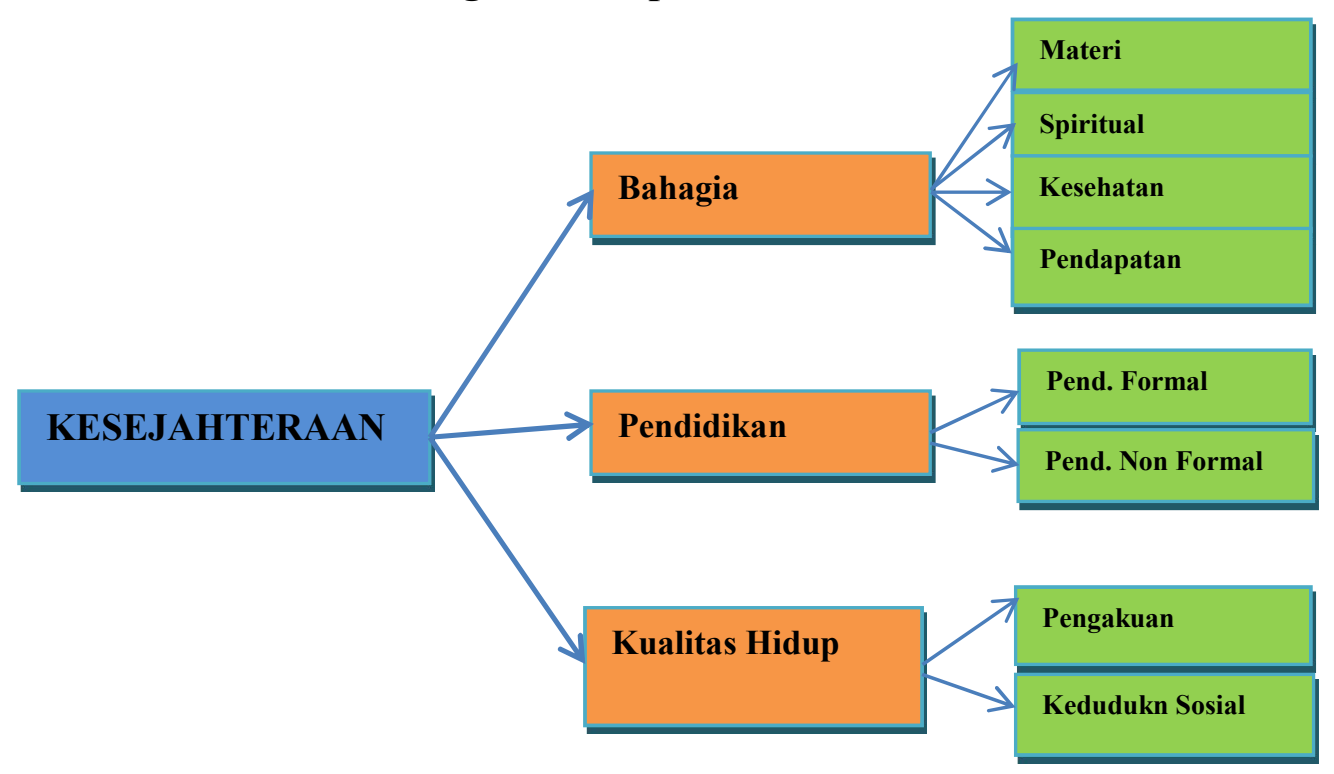

\section{Teknik Analisis}

Analisa data kuliatatif secara khas adalah suatu proses yang interaktif. Dalam penelitian ini menggunakan modela analisis intraktif model Miles and Huberman ( Prof.Dr.Sugiyono 2008 Metode Penelitian kuantitatif dan Penelitian Kualitatif hal.:246-252). Analisi interaktif Miles and Huberman merupakan model analisi yang terdiri dari :

1. Pengumpulan data (data collection), 
2. Reduksi data (data reduction),

3. Penyajian data (data display),

4. Penarikan kesimpulan atau verifikasi (ferifikation).

Gambar 2.

Model Analisis Interaktif oleh Miles dan Huberman

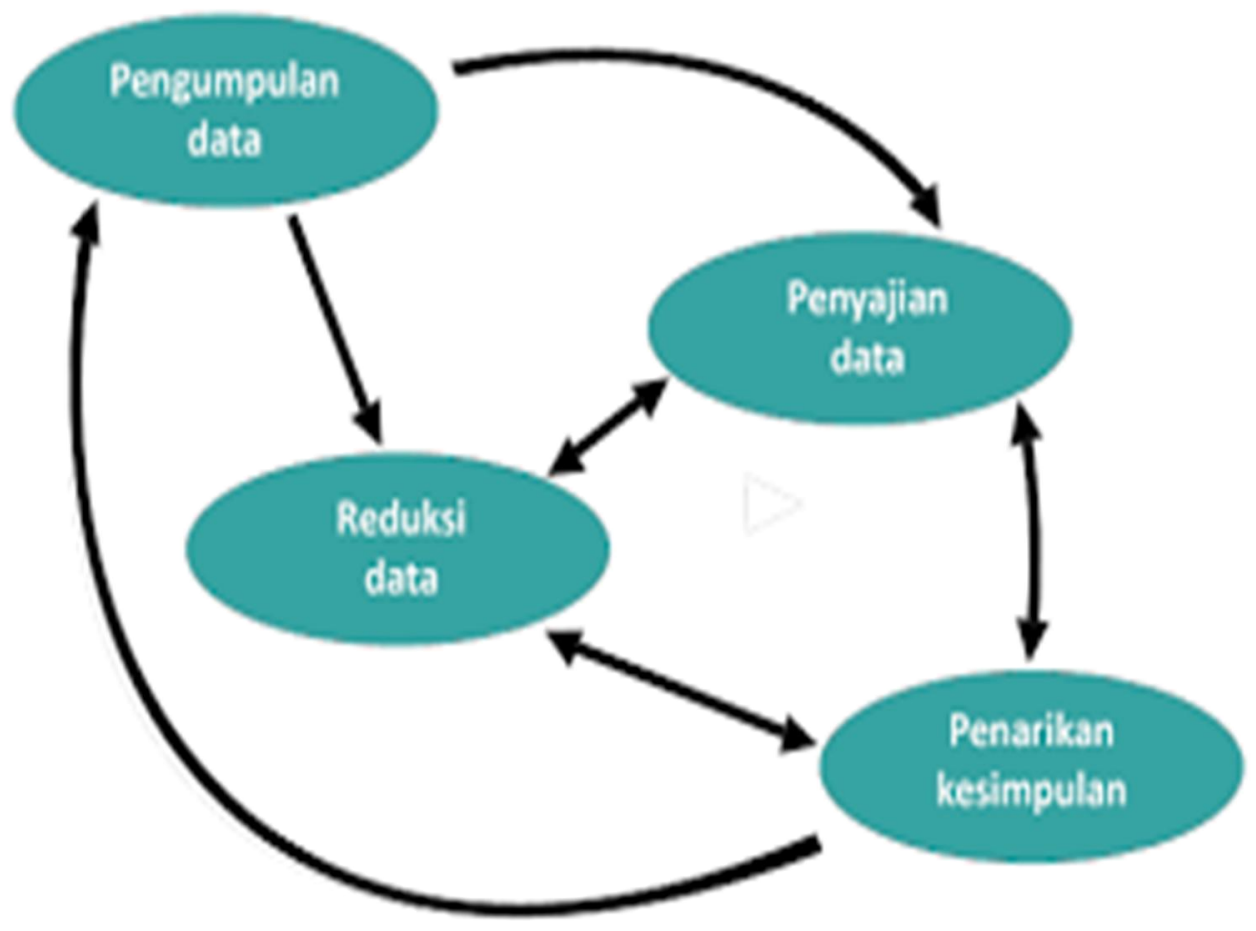

\section{Teknik Validasi Data}

Validasi bentuk batasan keseluruhan data yang diperoleh dan benar-benar merupakan variabel yang diinginkan mulai proses pengumpuln data yang tepat hingga penarikan kesimpulan sebagai hasil penlitian. Terdapat macam validasi yaitu validasi internal, validasi tingkat generalisasi dan validasi relevansi (Daymon \&Holloway, 2008:140). Validasi internal dalam penelitian ini dilakukan dengan cara membercheck kepada informan dengan menunjukan data yang berbeda sehingga meminta konfirmasi ulang yang melibatkan penafsiran peneliti dan persepsi orang yang terlibat.

\section{HASIL PENELITIAN DAN PEMBAHASAN.}

Kehidupan yang sejahtera adalah harapan setiap individu. Berbagai macam upaya di lakukan untuk mendapatkan penghidupan yang layak terpenuhi segala kebutuhanya. Kegiatan-kegiatan yang ada dimasyarakat, kelompokkelompok masyarakt di bentuk salah satunya adalah sebagai jembatan sarana untuk mencapai peningkatan kehidupan baik dari segi materi, kesehatan, pengetahuan ataupun pendapatan Seperti yang disampaikan oleh ibu mudrikah produsen nasi pecel; 
"kegiatan koperasi ini simpan pinjami ada pertemunya satu bulan sekali dua pertemuan pertama petemuan kelompok ini anggota yang punya hutang-hutang itu nganggsur lewat. Kemudian pertemuan yang kedua setiap tanggal 15 pencairan bagi anggot yang pinjampencairanya setiap tanggal 1syaratnya pinjam mereka harus punya usaha atau buat usaha modal usaha saya ini saya pinjam dari koperasi dan dari usaha saya ini saya hidup bisa memenuhi kebutuhan saya sehari-hari, awalnya usaha saya ini dulu aqu galon dan gas sekarang saya buka warung nasi pecel ini, di proyek ada dan baru dibuka di kaloka. alhamdulillah sekarang saya tidak bingung lagi"

pendapat ini diperjelas lagi oleh bu sri wahyuni;

"kegiatan koperasi saya ini simpan pinjam, setiap satu bulan sekali ada pertemuan kelompok bagi anggota yang mau ngangsur stelah itu diisi pegajian ibu-ibu nggota koperasi yang datang, malah ada kemarin itu ada anggota yang menginginkan diadakan belajar membaca alquran mereka seneng karena ada sebagian anggota itu memag belum ada yang bisa baca trus ada yang minta mendatangakan dinas kesehatan dan ada juga yang minta satu bulan sekali prkatek membuat kue, Wong wedok kui lek ketemu ora enek enteki ada saja yang dibicarakan tambah ilmu mbak kadang ada info 2 itu cepet nyampek pokoke seneng"

Kegiatan-kegiatan yang dilakukan dalam suatu kelompok mampu membentuk sikap untuk melakukan kegiatan yang mampu memenuhi kebutuhan hidup. Fasilitas pinjaman modal usaha yang berikan koperasi kepada anggotanya mampu membentuk pemikiran untuk memanfaatkan peluang membuat dan mengemangkan usaha sehingga bisa memenuhi kebutuhan sehari-hari. Selain itu kegiatan-kegiatan yang dilakukan kelompok mampu memotifasi diri untuk memperbaiki pribadi yang lebih baik lagi dengan diadakanya pengajianpengajian, meningkatkan pengetahuan kesehatan, pengetahuan ketrampilan dan pengetahuan-pengetahuan lainya Karena didalam pertemuan kelompok ini mereka mendapatkan informasi-informasi yang dibutuhkan. Disinilah peran koperasi sangat dirasakan mampu memenuhi kebutuhan anggotanya hal ini sesuai dengan Undang-undang koperasi no 25 tahun 1992 BAB III pasal 43 ayat 1 yang berbunyi"usaha koperasi adalah usaha yang berkaitan langsung dengan kepentingan anggota untuk meningkatkan usaha dan kesejahteraan anggota"

Kesejahteraan tidak hanya di ukur dari tingkat tercukupi segala kebutuhan sehari-hari tapi juga tingkat pendidikan adalah salah satu harapan bagi setiap masyarakat seperti yang disampaikan oleh Wiji Suswati;

"manfaatnya jadi anggota koperasi banyak, saya pinjam di koperasi buat tambah modal usaha konveksi saya, kadang kalau anak saya yang kuliah di jogja minta kiriman saya pinjamkan di koperasi. Anggota itu banyak yang pinjam koperasi untuk keperluan sekolah anak-anaknya apalagi pas tahun ajaran baru yang ngajukan pinjaman banyak, karena dikoperasi kita itu pinjaman untuk kebutuhan yang sangat penting itu didulukan misalnya untuk orang sakit dan untuk keperluan sekolah dan dana di koperasi kita terbatas jadi gak bisa memenuhi semua permintaan, biar 
mereka kebagian semua akhirnya dibagi jadi dapatnya separo dari pengajuan.".

Sejalan dengan apa yang disampaikan oleh binti Fatimah;

Iya bu, bagimanapun punya usaha sendiri itu seneng saya lebih mandiri saya sekolah lagi kuliah ini juga biaya dari usaha saya ini, saya gak mau terlalu membebani keluarga anak saya kuliah masih semester 4 dan yang satu masih SMA jadi saya harus punya pendapatan sendiri.

Dengan adanya koperasi mampu membantu anggotanya untuk meningkatkan pendidikan, modal untuk mengembangkan usaha diperoleh dari koperasi dari usahanya tersebut mampu membantu untuk mencukupi biaya pendidikan. Selain itu di dalam dalam memberikan pijaman mengutamakan berdasarkan kepentingan dan kebutuhn anggota yaitu kesehehatan (orang sakit) dan pendidikan. Di dalam melaksanakan kegiatan koperasi ini sesuai dengan tujuan dari pemerintah yang tertuang di dalam pembukaan UUD 1945 alenia ke empat yang berbunyi "kemudian daripada itu untuk membentuk suatu pemerintahan Negara Indonesia yang melindungi segenap bangsa Indonesia dan seluruh tumpah darah Indonesia dan untuk memajukan kesejahteraan umum, Mencerdaskan kehidupan bangsa dan ikut melaksanakan ketertiban dunia yang berdasarkan kemerdekaan, perdamaian abadi dan keadilan sosial,maka disusunlah kemerdekaaan kebangsaan itu dalam suatu Undang-undang Dasar Negara Republik Indonesia...,"

Pengakuan akan keahlian dan keberadanya di tengah kelompok masyarakat merupakan kebanggaan tersendiri, " Kalau menurut saya Sejahtera itu kebutuhan terpenuhi, bisa sekolah, punya pendapatan yang sendiri, dan yang penting kehidupanya lebih baik dari yang dulu. Sekarang saya juga sering mendapat undangan dari kelompok maupun dari dinas menjadi narasumber palatihan membuat kue...banyak juga teman-teman yang datang kesini tanyatanya ada teman yang dari kalimantan telepon minta pendapat usaha apa yang cocok karena di lingkungannya banyak pisang yang kurang dimanfaatkan, ada juga mahasiswa yang kesini studi banding... ya alhamdulilah seneng bisa dipercaya masyarakat" bu binti ketua forum koperasi wanita juga pengurus forum koperasi wanita Kabupaten Blitar. Hal ini diperjelas lagi oleh zakiyatun pengusaha batik zaki;

"Alhamdulillah saya dipercaya mewakili kabupatem Blitar untuk menampilkan batik saya di acara Jatim Nigh Carnival dan sering juga sekolahan-sekolahan itu ngundang saya minta ngajari membatik".

Kepercayaan dari masyarakat dan pemerintah akan kemampuanya untuk menjadi narasumber, dimintai pendapat dan mewakili pemerintah setempat untuk membawa daerahnya ini merupakan kebanggaan tersendiri karena tidak semua orang mendapatkan kepercayaan seperti ini. Pemerintah daerah memberikan kepercayaan kepada mereka untuk mewakili daerah salah satunya percaya akan kualitas dari produknya. Kepercayaan dan pengakuan inilah yang akan meningkatkan motivasi sehingga kegiatanyan dalam mengaktulisasikan diri ke dalam kegiatan yang bermanfaat.

Dari penjelasan diatas kegiatan yang dilaksanakan koperasi waita sesuai dengan UU Koperasi nomor tahun 1992 tentang tujuan koperasi yaitu pasal 3 
yang berbunyi "Koperasi ertujuan memajukan kesejahteraan anggota pada khususnya dan masyarakat pada umumnya serta ikut membangun tatanan perekonomian Nasional dalam rangka mewujudkan masyarakat yang maju, adl dan makmur berlandaskan pancasila dan undang-undang dasar 1945", dan sesusi dengan fungsi dan peran koperasi pasal 4 yang berbunyi yaitu : (1). Membangun dan mengembangkan potensi dan kemampuan ekonomi anggota pada khususny dan masyarakat pada umumnya untuk meningkatkan kesejahteraan ekonomi dan sosialnya. (2). Berperan serrta secara aktif dalam upaya mempertinggi kualitas kehidupan manusia dan masyarakat. (3). Memperkokoh perekonomian rakyat sebagai dasar kekuatan dan ketahanan perekonomian nasional dengan koperasi sebagai sokogurunya. (4). Berusaha untuk mewujudkan dan mengembangkan perekonomian nasional yang merupakan usaha bersama berdasar atas asas kekeluargaan dan demokrasi ekonomi".

\section{Kesimpulan dan Saran}

Tujuan dari koperasi khususnya koperasi wanita adalah untuk meningkatkan kesejahteraan anggota pada khususnya dan masyarakat pada umumnya. Kesejahteraan yang dimaksud adalah dimana kebutuhan terpenuhi yaitu:

1. bahagia yaitu terpenuhi kebutuhan hidup yaitu terpenuhinya pangan sandang dan papan, rohani yaitu adanya ketenangan hidup lebih religi, kesehatan yaitu badan yang sehat tidak sakit dan pekerjaan yang layak yaitu pendapatan yang didapat mampu memenuhi kebutuhan hidup.

2. Pendidikan, yaitu mendapatkan pendidikan yang diinginkan

3. Kualiatas hidup yaitu pengakuan akan kemampuan dan pengetahuan yang dimiliki sehingga merasakan hidup lebih bermakna

Untuk mempertahankan dan meningkatkan dari kesejahteran anggota dan masyarakat tesebut perlu dilakukan kerjasama dari berbagai pihak terutama pemerintah yaitu dintaranya"

1. Menjaga kestabilan harga kebutuhan pokok agar harga kebutuhan pokok dapat terjangkau oleh masyarakat.

2. Menumbuhkembangkan kewirausahaan

3. Biaya pendidikan yang terjangkau sehingga masyarakat bisa mendapatkan pendidikan.

4. Meningkatkan dan mengembangkan ketrampilan masyarakat melalui kelompok-kelompok masyarakat.

\section{DAFTAR PUSTAKA}

Andreas Harefa. 2007. Inovasi Kewirausahaan untuk Semua Orang. Jakarta: Gramedia Pustaka Utama

Anwar Sanusi, SE.,M.si. 2003 ; Metodologi Penelitian Praktis untuk ilmu Sosial dan Ekonomi. Malang, Buntara media

Arifin Sitio, Haloman Tamba. 2001. Koperasi teori dan Praktek. Jakarta:Erlangga.

Aristoteles dalam Kirdi Dipoyudo, Keadilan Sosial, Jakarta: CV. Rajawali 
Daulay, Harmona. 2006. Pemberdayaan Perempuan: Studi Kasus Pedagang Jamu di Geding Johor Medan. Jurnal Harmoni Sosial, Volume I Nomor I, September 2006.

Drs.Sumanto.M.A. , 1995 , Metodologi Penelitian Sosial Dan Pendidikan, Yogyakarta : Andi Offse

Edi Suharrto,Ph.D,2009, "Kemiskinan dan Perlindungan Sosial di Indonesia, menggagas Model Jaminan Sosial Universal Bidang Kesehatan” Alfabeta , Bandung

Edi Suharrto,Ph.D, “Membangun Masyarakat Memberdayakan Rakyat” Kajian Strategis embangunan Kesejahteraan Sosial dan Pekerjaan Sosial, Refika Aditama, Bandung.

Hendar dan Kunadi ,.1990, Ekonomi Koperasi,Penerbit Fakultas Ekonomi Universitas Indonesia, Jakarta

Husodo, S.,Y., 2006 pancasila : jalan menuju negara kesejahteraan, yogyakarta, 14 agustus 2006

Isbandi Rukminto Adi, 2013, "Intervensi Komunitas dan Pengembangan Masyarakat Sebagai Upaya Pemberdayaan Masyarakat”, Rajawali Pers, Jakarta

Jim Ife Frank Tesoriero,2008, “Alternatif Pengembangan Masyarakat di Era Globalisasi (Community Development)”, Pustaka Belajar Yogyakarta.

Martono, Nanang. 2011. Sosiologi Perubahan Sosial: Perspektif Klasik, Modern, Posmodern, dan Poskolonial. Rajawali Press: Jakarta.

Muhadji, Noeng. Metodologi Penelitian Kualitatif.Yogyakarta:

Munandar A.S. (1981:9). Pengembangan SDM dalam rangka Pembangunan Nasioal. Jakarta : LPPM

Muttalib, Jang A. 1993. Menggunakan Kerangka Pemampuan Wanita, dalam Moeljarto Tjokrowinoto, dkk. Bahan Pelatihan Jender dan Pembangunan. Kantor Menteri Negara UPW.

Novian, Budhy. 2010. Sekilas Tenang Pemberdayaan Perempuan. Artikel Sanggar Kegiatan Belajar Kota Pangkalpinang, Kepulauan Bangka Belitung.

Patilima, Hamid. 2005. Metode Penelitian Kualitatif. Bandung: Alfabeta

Ropke, John, 1995. Kewirausahaan Koperasi.Jatinangor :UPT Penerbitan IKOPIN

Soemardjan, S., 1991. Pancasila dalam kehidupan sosial, Jakarta : BP 7 pusat

Sugiyoo, Pro,Dr, 2008, Metode Penelitian Kuantitatif, Kualitatif dan $\boldsymbol{R} \& D$, Alfabeta Bandung.

Sonhaji, Ahmad.1994.Penelitian Kualitatif dalam Bidang Ilmu-Ilmu Sosial dan Keagamaan.Malang:Kalimasada Press

Sugiyono. 2008. Memahami Penelitian Kualitatif. Bandung: Alfabeta

Tan, Mely G. 1995. Perempuan dan Pemberdayaan. Makalah dalam Kongres Ikatan Sosiologi Indonesia (ISI). Ujung Pandang.

Titik dan Rahman, 2014, Ekonomi Skala Kecil / Menengah dan Koperasi. Bogor: Ghalia Indonesia.

Undang-Undang Dasar 1945

Undang-undang Koperasi No 25 tahun 1992. 